\title{
Illegal abortions and the Soviet health service
}

\author{
MICHAEL RYAN
}

At first glance it seems improbable that illegal abortions could be occurring on any substantial scale in the Soviet Union today. Although termination of pregnancy had been banned in 1936, during Stalin's rule, the relevant legislative provision was abolished in November 1955. Interestingly enough, the order that effected that reversal in social policy incorporates the following specific rationale: "Revocation of the prohibition on abortions will create the opportunity to eliminate the great damage caused to women's health by abortions which are performed outwith curative institutions, often by ignorant persons."

Related to that confident prediction was a strategy that has a direct bearing on the question of what constitutes an illegal abortion. Thus the order refers to the "criminal liability" of doctors, as well as persons lacking medical education, who perform abortions "outwith hospitals and other curative institutions." Since all such units are state owned it follows that private practice in this connection is categorised as an offence under the criminal code.

\section{Extent of the problem}

That large numbers of legal abortions take place is well known; indeed the Soviet health service holds an unenviable record for terminating far more pregnancies than it welcomes babies into this world. The balance has been changing for the better, however, from the pronatalist viewpoint; when scattered data are pieced together a substantial improvement can be seen to have occurred in the ratio of live births to terminations of pregnancy. Two decades ago, according to sample surveys, the ratios were as follows: $1962-1: 3 \cdot 2 ; 1963-$ $1: 3 \cdot 7 ; 1965-1: 3 \cdot 9 ; 1966-1: 3 \cdot 9$; and 1967-1:4.'

By contrast, a study cited in a recently published book records the much lower ratio of 1:2.08 (for the late 'seventies or early 'eighties). ${ }^{2}$ Concealed in this average, as in so many relating to the Soviet Union as a whole, are wide variations between regions and between the various ethnic groups. For example, among Russian women in Alma Ata (capital of the Kazakh republic) the ratio of live births to terminations stood at an extraordinary high level of 1:5:9.

Given that the health service performs terminations on such a massive scale, it might be inferred that there are now relatively few illegal abortions - that is, those that occur outside health service units. In fact, such an inference is authoritatively disproved by the study mentioned above. Incidentally, it makes clear that the extent of this sociomedical problem is significantly understated by the statistics available because the sample surveys that generated them used health service information on patients admitted for treatment Centre of Russian and East European Studies, University College of Swansea,
Swansea SA2 8PP

MICHAEL RYAN, PHD, lecturer in politics and Russian studies after complications. Not all the women who had undergone an illegal abortion would have required admission to hospital and some who suffered complications would have relied solely on self medication.

However much of an underestimate it is, the reported frequency may be thought astonishingly high-at a ratio of one illegal abortion for every 2.7 legal terminations. And in a statement on which comment would be superfluous the source shows that "their first pregnancy was resolved by means of a criminal abortion by $67 \%$ of women and in the age group up to 19 years by $87.5 \%$." The latter figure was also presented in a disaggregated form to show that first pregnancies were illegally aborted by $70 \%$ of girls in towns and by $90 \%$ in rural areas.

\section{Role of the health service}

When attempting to explain the incidence of illegal abortions-a puzzle that forms part of "the mystery that is Russia"-a researcher might hypothesise the existence of a financial barrier in the form of a charge for termination of pregnancy carried out in health service units. It seems clear, however, that patients make only a small payment or else none.

Still at a theoretical level of analysis, the figures might be interpreted as evidence of a vast amount of private practice by Soviet doctors with appropriate specialist skills working in their own or their patients' homes. But that interpretation neglects the presumably decisive contraindication of liability to criminal proceedings and the prospect of a prison sentence, should complications ensue. In any case, it simply does not square with empirical findings. The survey already quoted states that the highest incidence of abortions occurs in the age group up to 19 and of those girls who terminated their first pregnancy illegally three quarters did so by themselves (Russian: samostoyatelno).

Although the notion of demand led privatisation has little explanatory value in this connection, there still remains the possibility that a health service termination may have various deterrent features. Evidence that provides conclusive support for that view will now be examined.

It is officially recognised that one reason for illegal abortions is the length of the hospital waiting lists. Other organisational failings include lack of adequate publicity for the 12 week criterion and the dangers of undergoing an illegal abortion.

Perhaps more importantly, an article in the popular magazine Working Woman draws attention to the pain and sense of being treated as an inanimate object that health service patients experience. Underlying the often poor, and sometimes appalling, quality of care is a range of factors, which include shortages of anaesthetics, a conveyor belt approach (apparently the operation is performed in eight minutes), and the indifference, if not callousness, of health service staff.

Compounding the physical and psychological shock, not to mention adverse sequelae, is the patient's difficulty in preventing the reason for her hospital stay becoming public knowledge at work. 
This turns on the fact that doctors are required to record "abortion" as the reason for absence when completing certificates of temporary incapacity for work.

\section{Societal attitudes}

Naturally, it is possible to beat the system and, according to the article in Working Woman, a bribe of 30 roubles will do the trick as well as ensuring a degree of comfort and considerate treatment. Specifically in the case of women doctors, professional solidarity can guarantee that no record of the operation will exist. ${ }^{3}$ Generally, however, the health service takes no account of a woman's need for a protective cloak of anonymity. That is all the more necessary on account of the strongly negative attitudes that premarital and extramarital pregnancies continue to evoke in a society that frequently demonstrates a high degree of social conservatism.

Given the prevalence of social and parental disapproval, it is to say the least an unfortunate rule that a girl under the age of 18 who is seeking a legal abortion has to be accompanied by her mother. This requirement is referred to in a novel by the Moscow surgeon Yuli Krelin and, although I can not corroborate it, I consider that its existence in reality is essential to the credibility of one episode.

Krelin's quasiautobiographical hero, though after much persuasion, agrees to perform a criminal abortion on a schoolgirl of 17 who has protested that "they will simply kill me at home." He recounts to his friends how, in a country area some years before, a similar girl had threatened to hang herself rather than face her parents. He had said "go back to your parents and confess." Half an hour later they discovered her dead body. ${ }^{4}$

Consideration of both legal and illegal abortions in a wider perspective is bound to entail large questions about the failure of the Soviet state to ensure the provision of adequate sex education, family planning advice, and the supply of user acceptable and effective contraceptive methods. The deficiencies that lie within the remit of the health service must be accounted all the more remarkable because a concern with prophylaxis ranks high among asserted principles of Soviet medical practice.

While Soviet specialists do not draw attention to a fundamental contradiction in this connection, it seems possible that they have hopes of influencing the policy makers in favour of measures to raise the level of public awareness about contraception. Certainly some have gone as far as to advocate the supply of contraceptives without charge or at a reduced cost.

\section{Lives to be saved}

The specialists would be aware of the findings that knowledge of the possibility and means of preventing unwanted pregnancies is positively correlated with a woman's age, level of education, duration of marriage, and the number of abortiess that she has had. They would also know that the reported failure to use contraceptives rose to $80 \%$ among women who had illegal abortions. ${ }^{2}$

Given the existence of Mikhhail Gorbachov's policy of glasnost (openness, open reporting), the ordinary citizen is also becoming better informed about the dimensions of a major social problem that has been largely obscured or concealed by deep rooted prudery. Whatever the validity of that conjecture, readers of Working Woman could hardly have missed the chilling statement that $30 \%$ of illegal abortions end in a woman's death.

I thank Ms Barbara Holland for the reference from Rabotnitsa.

\section{References}

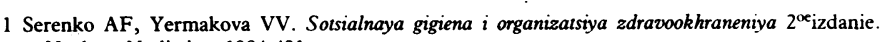
Moskva: Meditsina, 1984:431.

2 Bednii MS. Demograficheskie faktori zdorozya. Moskva: Finansi i statistika, 1984:112-7.

3 Vaseka V. Chisto muzhskoi razgovor. Rabotnitsa 1986;6:21.

4 Krelin Yu. Ot mira sevo. Khirurg; povest i roman. Moskva: Sovetskii pisatel, 1976:424-7.

\title{
Medicolegal
}

\section{The penalties of issuing misleading advertisements}

\author{
CLARE DYER
}

Roussel Laboratories is appealing against its conviction by a jury at the Old Bailey on 19 December on charges of issuing a misleading advertisement, and the appeal is likely to be heard in June or July. Also appealing is the company's medical director, Dr Christopher Good, found guilty of consenting and conniving at the issue of the advertisement. The advertisement was for the non-steroidal antiinflammatory drug Surgam (tiaprofenic acid), which appeared five times in the $B M \mathcal{F}$ between March and June 1983.

The prosecution, brought by the Department of Health and

London NW1

CLARE DYER, BA, BLs, legal correspondent
Social Security under the Medicines Act 1968, is the first against a major drug company in the 14 years that the advertising provisions of the act have been in force. Only four previous prosecutions have been brought for breaches of the advertising provisions of the Medicines Act, all against individuals making false claims for products promoted on a small scale.

Roussel, a subsidiary of Hoechst, was accused of issuing an advertisement which was misleading because claims for "gastric protection and selective prostaglandin inhibition were not justified or substantiated by clinical or other appropriate studies." Part way through the trial the company and Dr Good were cleared of further charges that claims in the advertisement that Surgam was safer and had a smaller incidence of side effects than the most common nonsteroidal anti-inflammatory drug, indomethacin, had been made "in the absence of available evidence." Having found that there was "a preponderance of available evidence, particularly clinical trials, that accurately reflects the claim that Surgam was safer, had fewer 